Portland State University

PDXScholar

$12-14-2020$

\title{
Racial Gatekeeping in Country \& Hip-Hop Music
}

Cervanté Pope

Portland State University

Follow this and additional works at: https://pdxscholar.library.pdx.edu/honorstheses

Part of the Mass Communication Commons, Race and Ethnicity Commons, Social Psychology and Interaction Commons, and the Sociology of Culture Commons Let us know how access to this document benefits you.

\section{Recommended Citation}

Pope, Cervanté, "Racial Gatekeeping in Country \& Hip-Hop Music" (2020). University Honors Theses. Paper 957.

https://doi.org/10.15760/honors.980

This Thesis is brought to you for free and open access. It has been accepted for inclusion in University Honors Theses by an authorized administrator of PDXScholar. Please contact us if we can make this document more accessible: pdxscholar@pdx.edu. 
Racial Gatekeeping in Country \& Hip-Hop Music

By

Cervanté Pope

Student ID \#: 947767021

Portland State University 


\section{$\underline{\text { Introduction }}$}

In mass communication, gatekeeping refers to how information is edited, shaped and controlled in efforts to construct a "social reality" (Shoemaker, Eichholz, Kim, \& Wrigley, 2001). Gatekeeping has expanded into other fields throughout the years, with its concepts growing more and more easily applicable in many other aspects of life. One way it presents itself is in regard to racial inclusion and equality, and despite the headway we've seemingly made as a society, we are still lightyears away from where we need to be. Because of this, the concept of cultural property has become even more paramount, as a means for keeping one's cultural history and identity preserved. Blacks and whites similarly, along with other races and backgrounds, attempt to protect or preserve facets of their culture they feel belong to them. What's different for both of these racial groups is how these cultural preservations are talked about, perceived and managed within the larger whole of society, as well as the fact that one seems more protecting or preserving than the other.

This can come as tangible artifacts, like what's typically preserved in museum exhibitions, though some of the most effective conservation methods come from passing along of oral and aural histories. Music ends up being a good example of cultural symbol in each of these ways, as lyrics are often narratives of experiences, and the actual music itself can communicate those narratives in a different fashion. With the diverse offering of backgrounds in the United States particularly, it's easy for a split in genres to occur; this is especially true for two genres that are as racially polarized as they are characteristically different-hip-hop and country. Each of these are dominated by one race, Black and white respectively, in their representation in the music industry, though their fanbases tend to cross the racial lines more effectively. There are artists of the opposite "designated" race who sometimes seek success in the opposing arena- 
their success and reception levels varying greatly. A lot of it has to do with the perceived authenticity of the artist, but in a bigger sense, it has to do with the way these artists are manufactured and sold to the fans.

Because music can be thought of as cultural property, it would seem that the different races have some type of ownership over these musical categories. This possession of genres has caused a "rap is for Blacks, country is for whites" rhetoric to exist for years, though we are finally reaching a time in music when artists are fixating on crossing those lines. There have been instances throughout the years where Black artists have found success in non-Black genres and whites have found success in non-white genres, but there hasn't been a time in modern music where a large force in the music industry was so stringently against an artist's efforts to succeed in a genre.

An example of this would be the issue with the rapper Lil Nas X and his 2019 smash hit, which is still on the charts, titled "Old Town Road," and the music conglomerate Billboard. There was something about Lil Nas X and his single that was different to Billboard that led him to be gatekept by that faction of the music industry. Looking at it in broader terms, in what ways does an artist's identity (encompassing everything from their race, sexual and gender identity, and talent) affect the social discourse of the music industry about them and, subsequently, how they intend to have that artist perceived by the public? In this essay I examine how cultural gatekeeping is different for Blacks and whites within the music industry, and the mechanisms in place that make it the way it is. Ideally, my findings will contribute to the discussion of what Black music is, what White music is, and who really has the right to say who gets to make either of them. 


\section{$\underline{\text { Rap \& Hip-hop }}$}

Often used synonymously, what defines rap and hip-hop is fairly simple elementally, though it's very easy to authentically spot, and even more easy for people to inauthentically reproduce. As a genre, rap is characterized as rhythmically chanted speech that is “accompanied” by a musical arrangement (Encyclopædia Britannica, 2020). As is also defined

here, the supporting music that goes along with the chanted speech can be referred to as hip-hop, and can include sounds sampled or taken from other songs and recordings (Encyclopædia Britannica, 2020; Merriam-Webster, 2020). Something that encyclopedias and dictionaries also recognize is how the term hip-hop is predominantly used to describe the movement surrounds the culture and how that culture changes as the movement changes with the different eras. For instance, much of the defined culture surrounding rap involves graffiti art, breakdancing, deejaying, and certain fashion choices. The graffiti and breakdancing aspects are more associated with the original 80 s era of the genre while the next phase, 90s gangsta rap, leaned heavily on drugs, violence, criminal behavior and degradation of women. The current phase, classified as mumble or trap rap, is signalized particularly by heavily tattooed skin (especially tattoos on the face) and interesting fashion choices. In regard to hip-hop as a musical term, it was first coined by Keith Cowboy of Grandmaster Flash and the Furious Five and adapted into what's considered the first song to commercial rap, Sugarhill Gang's "Rappers Delight" (FuriousFive.net, 2006). Afrika Bambaataa of the Universal Zulu Nation is acknowledged as the first to use the term to describe the culture.

\section{Country}


As a genre, country music is defined as a style of roots music, originating in the 1920s, that mixes blues with American folk elements. Specifically, country music's foundation is built on North American “old-time," which is characterized by fairly simple song structures that incorporate the use of folk lyrics, harmonicas and acoustic string instruments like banjos and fiddles. The genre, which used to be referred to as "hillbilly music" until the term "country" became widely in use in the 1940s (Russell, 2007), gets its origins from the popular ballads of early Appalachian colonists, which included Irish, Scottish and English settlers (Encyclopedia Brittanica, 2020). The first iterations of country emerged from Atlanta, Georgia, where an old time fiddlers James Gideon "Gid" Tanner, Henry Gilliland, A.C. (Eck) Robertson, and Fiddlin' John Carson, were credited with starting the first generation of country. Fiddlin' John Carson is also recognized as having the first country song to play over radio airwaves that featured vocals and lyrics with "Little Log Cabin in the Lane" for New York's Okeh Records in 1923 (New Georgia Encyclopedia, 2015). The first nationwide country hit came in 1924 when Vernon Dalhart's version of the folk ballad "Wreck of the Old 97" was the first to sell one million copies.

Like hip-hop, country has gone through different phases or generations. The second generation saw the most innovation for the genre, as many different elements and subgenres began to emerge. The decade of the 1930s saw the development of rockabilly, honky tonk, bluegrass, western swing and more, along with the use of drums (Encyclopedia Brittanica, 2020). Following generations brought about outlaw country, country-pop, bro-country and the rise of female country singers.

\section{Case Background}


In December of 2018, Montero Lamar Hill independently released a song on YouTube called "Old Town Road," under the moniker Lil Nas X. At the same time, he uploaded it onto the music streaming services SoundCloud and iTunes, tagging it under the "country" genre. The song eventually took off, garnering massive amounts of attention on social media platforms like TikTok and Twitter, causing viral meme trends and engagement among users. This led to major label attention, constant radio airplay and a remix featuring known country singer Billy Ray Cyrus. Hill's song quickly scaled Billboard's Hot Country Songs chart yet faced a major issue while on its way up-Billboard didn't want it on there. Despite its characteristic country elements, Billboard claimed it didn't fall within the guises of the genre, though they allowed the song to remain on their Hot R\&B/Hip-Hop chart. While the media group claims the removal was purely based on an analysis of the song's rhythms and instrumental elements, it is a collective belief among music journalists and fans that the group's removal of the song is due to the fact that Hill is a young Black artist. This by no means would be the first time that country music has excluded Black artists. In contrast, categorically "Black” music hasn't always been the most receptive to White artists, either. It's a phenomenon that happens with many different popular music genres, but country and hip-hop are the most culturally guarded.

\section{Methodology}

One of the ways I will attempt to do this is by looking at rhetoric in the music industry surrounding Black artists and musicians who have tried their hand at making country music. To do this, we will be looking at how discourse is shared and distributed amongst the key players within the music industry — notably, music and culture journalists, label and brand executives, fellow artists and the musicians themselves. Some of these publications include The 
New York Times, Rolling Stone, Vulture and Vox among others, as they've given the most attention to the initial case, but also have credibility in the industry in addition to a diverse set of writers with varying opinions, knowledge and tenacity in doing research. Considering how the topic has many contributing factors, I will be doing a comparative study through media analysis of when Black artists have to tried to break into country music, or when White artists have entered hip-hop, rap, $R \& B$, soul and any other genre that falls into what is formally known as race music or race records (Ramsey, 2003). My focus will be on Lil Nas X and rapper Eminem as the main example of a white person making Black music successfully. I will analyze artist interviews, music reviews, album sales, music charts and rhetoric used by music journalists and fans regarding the genres in order to provide a foundation for why the genres operate in the ways they do. It should be noted that my sample of evidentiary information was pulled from articles, album reviews and industry commentary from the year 2019, as this was when the controversy was at the height of its coverage and attention. This is also when the 20 year anniversary of Eminem's debut happened to take place, so there were some more recent perspectives to be offered on the effects of the album itself and his presence within the industry. Because of this, neither artist's current standing within the music industry is reflected within this paper. While this could present itself as a limitation to my findings, it doesn't affect or change the fact that the treatment of white artists in comparison to Black artists is imbalanced. As well, I will use the terms rap and hip-hop interchangeably when referencing artists. Their conceptual definitions are different in reality, depending on who you ask. To some, rap is a reference to the lyricism while hip-hop focuses more on beats, which would make them similar but different genre-wise, likened to how doom metal and heavy metal are two sides of the same coin. In other circles, rap is the actual craft while hip-hop is the culture that encompasses it. My operational definition conflates 
the two more in the way the larger music industry does. When referring to the artists themselves, I also switch between their birth names and their stage names, depending on the context in which I am discussing them.

\section{Theoretical Frameworks}

In order to fully grasp and analyze the data collected, a theoretical framework was necessary to use for rooting the conclusions reached. There are many that can be applied.

Because the focus of this case has to do with conscious and subconscious "protection" and power that some hold (or feel as though they should hold) over certain genres, gatekeeping is a major factor in this process. By definition, gatekeeping is "process of culling and crafting countless bits of information into the limited number of messages that reach people every day, and it is the center of the media's role in modern public life. [...] This process determines not only which information is selected, but also what the content and nature of the messages, such as news, will be" (Shoemaker \& Vos, 2009). Going further, gatekeepers have an immense level of responsibility, as they "determine what becomes a person's social reality" (Shoemaker \& Vos, 2009). This type of power seeps into many absorbable facets, including music. As a response to this, the protection motivation theory also pertains to my analysis. R.W. Rogers $(1975,1983)$ stated that the protection motivation theory is based on protection from four components: how severe a person thinks something could be, how likely they feel it is to occur, how effective they feel preventative actions or behavior could be, and their own level of self efficacy. In the case of my thesis, the gatekeeping of musical genres on the point of either race would be a direct result of the protection motivation theory at play, because each race perceives the other as a threat to the ownership they feel they have over the genre, and thus enacts gatekeeping measures as a preventative action to protect that ownership. 
As hip-hop and country are so racially divided and controlled, frameworks that work within the racial realm were also helpful. In varying aspects of my research, I found critical race theory, racial formation theory, afrocentrism and protection motivation theory very applicable. Critical race theory was founded on the very blatant but often ignored notion that racism is engrained into every aspect of society and the ramifications are felt by many in many ways, including in all avenues that Black people have. According to Ford and Airhihenbuwa's (2010) analysis of the theory (specifically, the notion of ordinariness within the theory), racism and its different forms are such a part of everyday life for minorities that they've either grown to ignore it because it happens so often, or they become so hyperaware of it that every instance becomes racist. As well, the theory drives home that racism isn't the same as being racially conscious and being colorblind isn't the same as being nonracist (Bonilla-Silva, 2006 as cited in Ford \& Airhihenbuwa, 2010). Racial formation theory ties into this as well, as it deals with how race, especially within the United States, is socially, politically and economically constructed and "unstable," therefore making it capable of change (Omi \& Winant, 1986; 2015). The social construction aspect of this theory is key to my analysis, as it directly correlates to the idea that since race is socially and politically constructed, the cultural property (in this case, music genres) is merely a result of that construction, though one that is justified because of the ways race is perpetuated politically and economically. With Afrocentrism, the idea is to shift away from the dominant white lens and instead focus on people of African descent without a nationalist or superiority complex. While white supremacy and white nationalism center whiteness as what should be the norm, afrocentrism promotes and appreciates Africanness and Blackness in conjunction with as opposed to the "negation of whiteness," therefore "defining Blackness in positive terms" (Grealy, 2008). For the sake of my thesis, it works as a theoretical framework 
because it lends additional credence to why Black people look at rap and hip-hop, despite the negative connotations and subject matters surrounding it and put into it, as a representation of who they are in concurrence to who whites define them to be.

\section{$\underline{\text { Implications }}$}

Though there likely will never be a full and solid way of ridding the music industry of racist or supremacist tendencies, it's beneficial to look at exactly how these mechanisms still remain in place. With the recent occurrences regarding Lil Nas X and the country success Whites within the music industry didn't want him to have, many think this is a recent problem within entertainment. However, this has been an issue that has afflicted popular music dating back throughout entertainment history. My thesis ideally will provide a blueprint for the instances within the entertainment industry that allows for the racism within it to keep happening.

\section{Discourse Surrounding Lil Nas X}

Conflating the actions of Billboard with cultural gatekeeping isn't new-it was immediately addressed upon the incident happening. Washington Post journalist Mark Laver stated in a 2019 piece on the topic how "Clearly, for the self-deputized gatekeepers of the country genre, Lil Nas X and his song don't belong." He also points out in the article country music radio's "narrow playlists" and "aversions to playing songs by women.” As a genre, country music comes with a racially tied position of power that, despite its relegation by most fans as their least favorite, seems to be more heavily guarded than necessary. This seems more to do with the actual race of the individuals and less about the defining factors of country music itself. Many music critics, journalists and industry officials have pointed out that "Old Town Road" 
does sound country—Los Angeles Times journalist Marissa R. Moss even saying that its "banjo and backwoods moans" were the introduction to the future of country music (Los Angeles Times, 2019). It should be noted, however, that the banjo hook in "Old Town Road" is a sample pulled from the song "Ghosts IV-34" by industrial rock band Nine Inch Nails.

Moss spoke with Abe Stoklasa, a country songwriter who has penned hits for artists like Tim McGraw and Chris Lane, for the piece. Despite his admission to liking the song and thinking it's cool, he read unencumbered when saying how "Old Town Road" is a "novelty song" that "is not going to change the way we work." This aversion to change contributes to the genre's willfully archaic approach to preservation, which has led to some within the country discourse community to say that Lil Nas X's country designation was a cleverly crafted fluke to evade the heavy saturation of rap and hip-hop's current market. When speaking with Elias Leight of Rolling Stone (2019), Danny Kang, the co-manager of viral country childstar Mason Ramsey, doesn't falter in his assertion that country's shunning of Lil Nas X has nothing to do with race, instead saying it's a rejection of the way he tried to gain traction for the song. "He was going to these spaces, gaining a little bit of traction on their country charts, and there's a way to manipulate the algorithm to push your track to the top," says Kang. "That's favorable versus trying to go to the rap format to compete with the most popular songs in the world."

Even though Lil Nas X doesn't rap at all on the song (something that is definitely heard and acknowledged, especially by Laver), he attempted to delve even further into the country realm by including star Billy Ray Cyrus on a remix of the song. Cyrus was a long supporter of the song and was vocal about disagreeing with Billboard's decision before he was featured on the 
remix, tweeting "Don't try and think inside the box. Don't think outside the box. Think like there is no box. \#HorsesInTheBack" in March of 2019— the hashtag a lyric pulled from "Old Town Road." Nothing characteristic about the song changed with his addition, except for the fact that he got his own verse and became one highest stream songs of the year. Vox's Allegra Frank (2019) points out that Lil Nas X isn't the first artist to collaborate with a country musician on a song, though her other examples boast more reception from the country community. She references pop star Bebe Rexha’s 2017 "Meant to Be" featuring country stars Florida Georgia Line, pointing out that it spent a record-breaking 50 weeks at the top of the Hot Country Songs chart, the artists even receiving a Grammy nomination for the single. Frank also mentions another Florida Georgia Line song, 2012's "Cruise," which features rapper Nelly, and how it charted on both Billboard's Hot 100 and country charts, as well as being the most downloaded country song of all time. Country blog Save Country Music (as cited in Frank 2019) seems to ignore this context, or at least Lil Nas X's effort with Cyrus, saying that the track features no country artists and is "no more country than The Beastie Boys "High Plains Drifter," further insinuating that "there appears to be absolutely no credible reason to include this song on a country chart aside from a bigoted stereotype bred from the fact that horses and cowboy hats are referenced in the lyrics." This is contested by country singer Meghan Linsey, who very bluntly tweeted "That is some BS. "Old Town Road's got plenty of 'country elements 'and it's as 'country 'as anything on country radio, to be honest.” Lil Nas X is also heavily supported by Bobby Bones, who hosts a nationally syndicated country music radio show, and the programmer of Spotify's country playlists, John Marks (Leight 2019). 


\section{Country's Other Black Artists}

Even though Lil Nas X has received backlash for his country endeavors, he is certainly not the first Black artist to attempt at the country. On the contrary, there have been quite a few who have had lasting success within the genre. As Martin Hodgson stated in the Guardian ("The hidden faces of country, 2006), Black influence and musicians have been present in country since its first iterations, focusing on "universal themes" that reflect a working-class experience that isn't divided into black and white. Hodgson spoke with a Black touring country musician named Dwight Quick and his songwriting partner Frankie Staton, who founded the Black Country Music Association, who each back up this notion. "It's about my way of life," Quick told Hodgson. "You're not going to hear no rapper talking about fishing or drinking in a honkytonk or eating rabbit—but that's all me." Similarly, Staton reiterated how Black people have always participated in country music and like more than the typically Black genres of blues, rap, gospel and jazz. "The country music industry never asked us to come to the party... they call it America's music, but it don't look like America.”

This is painfully apparently to most outside of country executives, including Michelle Darrisaw, who penned a piece on the issue for Oprah Magazine. She praises Lil Nas X for his efforts, though provides a hefty list of other Black country artists who have come before him ("Old Town Road's Lil Nas X is Breaking Barriers-But He's Not the First Black Country Artist to Do It," 2019). She includes Petrella Ann Bonner, who declared herself the "First Lady of Country Soul" with a seven-album deep discography, a Billboard charting hit single and the accolades of being named "Songwriter of the Year" by the Tennessee Songwriters Association in 1994. Aaron Neville, Cowboy Troy and Darius Rucker of the incredibly famous Hootie and the 
Blowfish are also on the list, though the most prominent Black country superstar is Charley Pride.

Pride made his official music debut in 1966, though he had been playing as a self-taught musician for his teammates as a part of the Negro American League's Memphis Red Sox baseball team, where he was a semi-pro (Darrisaw, 2019). Pride was the first Black country singer to sign to a major label, landing on the top 10 country chart for his song "Just Between You and Me," which also gave him his first Grammy nomination. Hodgson (2006) spoke with Pride as well, who in the interview said he never encountered racism because "I was never Black, never coloured, never Afro-American. I was just always American, an individual," though that's refuted in his autobiography where he tells of his label RCA hiding information about him and photos from his press kits. Pride has stated how he's done all he could "to expand the country music audience," saying that the music industry may not "want any more Charley Prides" (Hodgson 2006).

This same story referred to a conversation with Tammy Genovese who, at the time, ran the Country Music Association (CMA). Her points were sad, yet indicative of the country picture that's been painted for years: "The black community's lifestyle is different from what we communicate with country music. We try to market to all types of people, but every culture has its own kind of music, and that is something we can't change. Black people have their own types of music that they like to listen to, be that jazz, hip hop or whatever."

\section{Discourse Surrounding Eminem}

Marshall Mathers, better known by his rap moniker as Eminem, made his rap world debut in 1997 with his single "Just Don't Give a F**ck." The track appeared originally on his Slim 
Shady EP, and was rerecorded and released on his major-label (via Aftermath Entertainment and Interscope Records) The Slim Shady LP, the following year. It was a strategic and advantageous debut single for the white artist, as it not only sampled infamous rapper Tupac Shakur's "I Don't Give a Fuck," but it also lyrically placed him within the confines of rap-based "street cred," so to speak. In a characteristic fashion, Mathers noted other white rappers (of varying success levels) in the song and touched on other common themes that pop up often in rap, including degradation of women. The single garnered most of its attention on its rerelease, particularly due to Mathers ' new support from another respected name in the rap game —-Dr. Dre. Once a former member of the esteemed rap group NWA, he had somewhat fallen off in success in the late 90s. Supporting Eminem was a career risk for him—other than signing Eminem to his label, he only produced three songs on the album and is a featured rapper on another. Still, his involvement was more beneficial to the new rapper's debut than it wasn't for reasons other than the weight his name holds in the rap realm.

At the time, Eminem's debut album was for the most part met with critical acclaim from both hip-hop blogs and major publications, and was discussed with excitement. Steve Juon of RapReviews related "Eminem's bark to DMX's bite," saying that the record was a stellar debut aside from the reworked version of "I Just Don't Give a F**k." Stephen Thomas Erlewine of AllMusic pointed out how it's nearly impossible to tell what of Eminem's lyrical narratives are fact or fallacy, which is part of what made the album one of the greater hip-hop debuts, and called out how the production was the perfect backdrop to highlight how "wildly gifted verbally" Eminem is. "At a time when many rappers were stuck in the stultifying swamp of gangsta clichés, Eminem broke through the hardcore murk by abandoning the genre's familiar themes and flaunting a style with more verbal muscle and imagination than any of his contemporaries" 
(Erlewine, undated). The A.V. Club noted how obviously needed Dr. Dre's involvement was in granting Eminem the necessary street credibility as someone who lacks melanin, also claiming how he started a "new musical subgenre of ostracized Midwestern geeks re-inventing themselves as subcultural icons" (Rabin, 1999). It should be noted, though, that before working with Dr. Dre, Mathers was a longtime collaborator with lesser known Black rappers and producers, such as the rap collective D-12 and his "rhyme partner" Royce Da 5'9".

With or without that credibility, Eminem's debut garnered much more positive attention from writers than negative, and as an artistic endeavor, is still held in that positive light. In revisiting the record for its 20th anniversary, Tom Breihan of Stereogum connected what Eminem is to Marshall Mathers to what Ziggy Stardust was for David Bowie_- "a grand and performative artifice" (2019). He also called out how despite most if not all of the lyrical content, which included songs that trivialized rape and abuse, didn't age well, that the record itself is still a considerable opus of talent unleashed. Will Lavin of NME called the record "groundbreaking" in his anniversary piece, touting how it made hip-hop more commercial and how it opened a door for white rappers to be received in better a manner than they were before him. "He earned the respect of a culture he knew he was a guest in and 'The Slim Shady LP' is what he used to gain admission” (Lavin, 2019).

\section{Hip-Hop's Other White Artists}

Eminem was by no means the first white rapper to release music, but he certainly was the first to reach a certain level of actual success. Before him, there was Vanilla Ice, Marky Mark, Everlast and the Beastie Boys in the public eye, while lyricists like Slug and El-P were gaining considerable traction in the underground scene. The success rate of white rappers pre-Eminem 
was high, though never reaching his specific heights. Even whites outside of rap were triumphant in the genre. As MTV's Carvell Wallace pointed out in 2016's “A Condensed History of White Rappers," the first two appearances of rap that occurred on the seminal music channel didn't even come from actual rappers. Debbie Harry of the new wave group Blondie has the first rap credit on the channel from the music video for the outfit's song "Rapture," which features a singular rapped verse nestled between synths and disco-type beats. "Rapture" was also the first song featuring rap to hit number one on Billboard charts. The second time rap hit the channel was from the mouth of a musician, but of a comedian. Rodney Dangerfield's 1983 novelty song and subsequent music video for "Rappin Rodney" had considerable airplay on the channel, with the song itself peaking at number 83 on the Billboard Hot 100 chart.

The Beastie Boys were the next to be prosperous within rap and hip-hop, making them one of the other most recognizable white names in the category. Their debut album Licensed to Ill, which was one of the first records to be released on the now infamous rap label Def Jam Records, broke records in 1986. It received rave reviews and was the first rap album to hit number one on the Billboard 200 chart, number two on the Top R\&B chart, as well as being the fastest selling Def Jam debut by selling over 100,000 in the first week of its release and hitting platinum status in less than three weeks (Wallace, 2016; Billboard, 2017). That led to the beginning iterations of the white rapper era of the 90s, starting with Vanilla Ice. Believed to be an industry plant who many referred to the "Elvis of Rap" upon his big break (New York Times, 1991), his debut track "Ice Ice Baby" was the first hip-hop song to reach number one on the Billboard Hot 100 track, as well as number six on their Hot R\&B/Hip-Hop Songs chart (Billboard, accessed 2020). The hook of the song sampled David Bowie and Queen's “Under 
Pressure" without credit, which led to legal issues for Ice, though it wasn't enough to stop the song's iconography. Other pre-Eminem white rap Billboard successes include Marky Mark and the Funky Bunch's, the rap group of actor Mark Wahlberg, "Good Vibrations," Snow's "Informer" and House of Pain's "Jump Around.” Post-Eminem hitmakers, though not always enjoyed by audiences of color themselves, include Macklemore, Limp Bizkit, Insane Clown Posse, Action Bronson, Paul Wall, G-Eazy, and Riff Raff, among many others.

\section{Analysis}

Though there is yet to be published academic information on Lil Nas X's presence in the music scene, there has been much to say about Eminem's. While he was supported by many Black artists within the industry, his existence within the culture is looked at much differently from an academic standpoint. Like many of the music and pop culture critics I've explored, Eminem's existence within Black music is conflated with Elvis's_-for good reason. In his piece "White Chocolate Soul” (2005), Mark Anthony Neal describes what is referred to as the "Elvis Effect." An idea originating from Paul C. Taylor, the Elvis Effect, which he insists could also be called the "Vanilla Ice Effect" or the "Benny Goodman Effect," is when a white artists becomes "proficient" in Black music and makes it easily discoverable to white audiences, which is where the Black music forms are then able to "reach widespread commercial acceptance" (Taylor, 1997 as cited in Neal, 2005). This commercial acceptance then makes it possible for these white performers to benefit financially from all of the aspects that go into the creating this music, including the "critical gatekeeping of the music" (Neal, 2005). In regard to Eminem, he was able to do this for successfully two reasons outside of his actual prowess with the elements of the 
genre-first, the audience that he ended up appealing to was looking for ways to grapple with their masculinity, and are drawn to the culture and style not hip-hop because of how it represents Black masculinity. Specifically, "the attraction to hip-hop is in part a response to the desire for culture which motivates white suburban consumers who believe they lack culture due to the normativity of whiteness in the United States" (Perry, 2004 p. 126). Eminem's raw and violent approach to lyrical narratives communicated the sort of masculinity these consumers were looking for. Wesley Morris, culture writer for the New York Times, calls this Eminem's "psychotic origami," further insinuating how Eminem was able to rap about rape, murder and violent acts against women in a carefree manner that wouldn't be and isn't afforded to Black artists, even with the free mechanisms of expression that Black music was supposed to create. "Particular to Black American music is the architecture to create a means by which singers and musicians can be completely free, free in the only way that would have been possible on a plantation..." Morris (2019) writes.

In contrast, there is no Elvis Effect for Black artists. Lil Nas X, be it with a genre cosigner like Dr. Dre was for Eminem (which he eventually had in Billy Ray Cyrus) or without one, or with the harsher version of racism that made it easier to steal from Blacks like in Elvis's era, was seemingly facing an entirely different undertaking. As both critical race theory and racial formation theory have pointed out, white supremacy and domination are rooted in everything, including the avenues and survival methods of Black people. The music industry was not willing to let Lil Nas X take over —at least, in chart-form—something that they've had control over and considered to be theirs. Even though "Old Town Road" had only reached the 19th position at the time it was pulled from the chart, his presence on the chart alone was deemed 
at least somewhat a risk to their hold on country as a genre. Even with the Black country artists who have had success in the past, how race and society were at their times of popularity was entirely different than the 2019 world that Lil Nas X debuted in. Much like how the racism of Elvis's time made it easier for him, the "Blacks as a form of entertainment without being humanized" type of minstrelsy has been an underlying factor in Black creative success for decades. In an era like this one, when Black people have more agency more than ever, Lil Nas X is an even bigger threat. There is something inherently more controversial and dangerous when it exists outside the norm, like Lil Nas $\mathrm{X}$ does in the mainstream, which invokes protection motivation within whites.

Even though country music has typically been a male dominated genre, there isn't the same connection to masculinity as there is with rap and hip-hop. Since it's rooted more in downhome traditional lyrics than what conveys virility, having some type of representative icon within country isn't something that Black audiences feel like they needed. Where country music and rap meet, along with their respective fans, is with the need for authenticity. Yet, the country canon is a contrived concept as it fails to acknowledge how it comes from Black performers and that its authenticity to whiteness is construction of culture. Laver (2019) called this out specifically, along with how "country music has always been entangled with Black culture," stating how the banjo is derived from West African string instruments like the ubaw-akwala and the ngoni.

When country music's gatekeepers - whether Billboard, country radio stations or white listeners - talk about genre, they tend to try to focus the conversation on musical sound. There 
is a sense that the sound of the music is neutral, objective terrain. Music has certain "elements" or it doesn 't; songs belong or they don't.

Because of this and how the of "Old Town Road" is driven by its banjo lick, Lil Nas X was technically well within country's authenticity regulations. From an afrocentric perspective, it's a modern way of celebrating the origins of Black music without necessarily detracting from how whiteness has affected it. Hip-hop, however, is less about about the sonic characteristics and more about the person behind them. As a genre of struggle and a form of escape that offers the opportunity to comment on life's strife, being from where you say you're from and actually dealing with what you're claiming to be dealing with is most important. That's why Vanilla Ice's rap career failed - it was discovered that his lyrical narratives about drive-by shootings and drugs were all made up. He conjured an upbringing that would liken him to the struggles Black artists rap about to establish some sort of closeness to African American adversity and access to their spaces, "relying on the ghetto as a "source of fabricated white authenticity"” (Eberhardt \& Freeman, 2015; Rose, 1994). Eminem was the exact opposite of this, growing up in a poorer, predominantly Black Detroit neighborhood. From a class perspective, Eminem follows hip-hop's authenticity guidelines, though he shifted his lyrical focus from rapping about his upbringing to using even more openly misogynistic and homophobic speech-both of which have been issues within hip-hop and the Black community in general. Still, Eminem's privilege allowed him to take his authenticity and seemingly flip it advantageously. First, he changes the "other" from being Black people to being mainstream media and the music industry, as well as middle and upper class whites and therefore positioning himself on the side of Black struggle. He decenters 
Black oppression and turns it into class oppression, where he as a white person can participate in and contribute to a conversation that wasn't meant for him (Grealy, 2008). Looking at this through a critical race theory lens, he's able to do this because of his whiteness, and how there's an overwhelming ownership that whites have (or feel the need to have) over everything.

\section{Discussion \& Conclusion}

In looking at the discourse surrounding Lil Nas X and other Black country musicians, namely Charley Pride, it's easy to conclude the ways in which gatekeeping and race theory play into what's been going on. From a gatekeeping standpoint, country music's executives and industry representatives feel as though country is something that is in need of protecting from marginalized persons, mainly Black and female-identifying musicians. Many of them, as Genovese so aptly broke down, feel as though there is a binary of experiences between white people and Black people, which must be communicated through the music genres that the industry has decided represents them respectively. Despite many within the industry acknowledging how Black people have been originators in country music as well as other genres, their credit still goes unreceived, as country music is still considered to be a white genre.

From a critical race theory standpoint, this erasure of talent, effort and, to a degree, existence, points to age old mechanisms that continue to suppress Blacks as individuals. Even as pioneers in most facets of society, deeply entrenched white supremacy, prejudice and discrimination allow for the continual denial of Black participation — at times come off as fullblown rejection of them as people. This translate into propaganda on the part of the country part of the music industry, as it attempts to promote and communicate a narrative that simply isn't 
true. Country music executives want audiences to believe that at least certain Black people don't belong within the genre to a degree.

\section{$\underline{\text { Limitations \& Further Research }}$}

There is more that needs to be explored and addressed regarding this issue. For starters, the fact that there have been white artists who have successfully made and profited off of stereotypically Black genres needs to be addressed. As well, I couldn't find any solid information regarding what exactly is about Lil Nas X, in comparison to the other acknowledged Black country artists, that made him the one to experience this. One possible reason for it could be the fact that he is only 20 years old, while the fact that he identifies as a gay man could be another, or that his choice of stage name flagged him as an "other" within the genre. Also, due to limitations with space, I did not include the numerous white country artists who have included elements of rap and hip-hop into their songs that were still designated as strictly country. It would be easy to apply critical race theory to this as well, as white supremacy and systemic racism allow for whites to take ownership and go against the rules they set for others. This too is another way in which this hypocrisy is propaganda, because it perpetuates this idea that white musicians are able to incorporate whatever elements of music they want to while still gaining recognition and success.

I also chose to specifically focus on the perception surrounding each artist's debut. It seemed like this would be the best part in each's career to do so, as whatever traction and hype they generated would've been organic to first impressions, and not built from any prior popularity. This could be a limitation considering the different eras in which each artist got their start. Since Eminem premiered in the much less internet driven era of the late 90s, marketing and promoting himself relied heavily on word-of-mouth, his ability to play local cyphers, which are 
rap battles and freestyle rhyme gatherings, actually tour and perform in different cities, and by sending mixtapes and albums to A\&R executives at labels. This is the original way artists would go about trying to get their music heard, which was a considerable hurdle for Eminem who couldn't hide behind the veil of the internet and had to confront the in-group of the rap world as an outsider. Lil Nas X dealt with the exact opposite, as he self-released his single himself on the internet in 2018 and allowed for social media to do a lot of that legwork for him. Part of what helped him get industry attention was the fact that his song was doing so well independently, though much if not all of that popularity was due to the younger, more internet- and social media-centric generation. As they tend to be less concerned with racial implications in different aspects of society, Hill's race wasn't something to cause a stir for them as much as industry executives who still work within more archaic margins.

The different in era that each artist came onto the scene could also have made a difference in their reception. What rap was in the 90 s was much different than what it is today, and truer to the original craft that it started with when the genre first popped up in the 80s. Today's country music is also quite different than what it used to be, which would lead one to think that the ways Hill incorporated country elements into "Old Town Road" would've tracked well enough with Billboard, who claimed it did not "not embrace enough elements of today's country music" (Leight, 2019). A good point for further research would be to look more closely into the debut songs of other artists of both races in these genres to see how they were critiqued for their stylistic elements. There have been white country artists within recent years who have included non-country components such as rap and rock into their songs, like Brantley Gilbert's 2014 single "Bottom's Up," the 2017 Sam Hunt single "Body Like a Back Road” or Kane 
Brown's "What Ifs," from the same year. All of these songs were well received but what separates them from Lil Nas $\mathrm{X}$ is that all of the artists are white (save for Kane Brown, who is half Black).

Other points that would be worth researching into is where both Lil Nas X and Eminem are now in their careers and how much, if at all, either of their standings have to do with previous controversies or media flare ups regarding race, sexuality or gender. Eminem has been quite vocal throughout his career about his feelings towards queer, gay and transgender persons — all of which are identities that are much more widely accepted socially now. He also hasn't been as popular presently as he was once was when exclusivity was more of the norm. Since the Billboard debacle, Lil Nas X has only grown in popularity, having a series of other successful songs, music videos and modeling gigs. 


\section{Bibliography}

Bonilla-Silva, E. (2006). Racism Without Racists: Color-Blind Racism and the Persistence of Racial Inequality in the United States (Second Edition). Rowman \& Littlefield Publishers.

Darrisaw, M. (2019, October 18). 7 Black Country Artists Who Paved the Way for the Viral Song "Old Town Road.” Oprah Magazine.

https://www.oprahmag.com/entertainment/a27182186/black-country-singers-lil-nas-X-old-town$\underline{\text { road/ }}$

Dionne, E. (2014, May 22). Hip Hop Is Not “Run” By Iggy Azalea, But It Sure Is Run By White Privilege. Bustle. https://www.bustle.com/articles/25400-hip-hop-is-not-run-by-iggyazalea-but-it-sure-is-run-by-white-privilege

Eberhardt, M., \& Freeman, K. (2015). "First things first, I'm the realest": Linguistic appropriation, white privilege, and the hip-hop persona of Iggy Azalea. Journal of Sociolinguistics, 19(3), 303-327. https://doi.org/10.1111/josl.12128

Fiddlin 'John Carson (ca. 1868-1949). (2015). New Georgia Encyclopedia. https://www.georgiaencyclopedia.org/articles/arts-culture/fiddlin-john-carson-ca-1868-1949 
Ford, C. L., \& Airhihenbuwa, C. O. (2010). Critical Race Theory, Race Equity, and Public Health: Toward Antiracism Praxis. American Journal of Public Health, 100(S1), S30S35. https://doi.org/10.2105/ajph.2009.171058

Fraley, T. (2009). I got a natural skill: Hip-hop, authenticity, and whiteness. Howard Journal of Communications, 20(1), 37-54. https://doi.org/10.1080/10646170802664979

Frank, A. (2019, April 5). Lil Nas X's "Old Town Road”: is it country music? Vox. https://www.vox.com/culture/2019/4/5/18295966/old-town-road-lil-nas-x-billy-ray-cyruscountry-rap-debate

Grealy, L. (2008). Negotiating cultural authenticity in hip-hop: Mimicry, whiteness and Eminem. Continuum, 22(6), 851-865. https://doi.org/10.1080/10304310802464821

hip-hop. (2020). The Merriam-Webster.Com Dictionary. https://www.merriamwebster.com/dictionary/hip-hop

Hodgson, M. (2017, February 15). The hidden faces of country. The Guardian. https://www.theguardian.com/music/2006/jul/16/folk

Jacobson, G. (2014). Racial Formation Theory and Systemic Racism in Hip-Hop Fans ' Perceptions. Sociological Forum, 30(3), 832-851. https://doi.org/10.1111/socf.12186 
KEITH COWBOY - THE REAL MC COY. (2006). Furious5.Net.

https://web.archive.org/web/20060317071002/http://www.furious5.net/cowboy.htm

Laver, M. (2019, June 20). Lil Nas X and the Continued Segregation of Country Music. The Washington Post. https://www.washingtonpost.com/outlook/2019/06/20/lil-nas-X-continued$\underline{\text { segregation-country-musicl }}$

Leight, E. (2019a, April 19). Fueled By Controversy, Lil Nas X's "Old Town Road” Is on a Record-Breaking Run. Rolling Stone. https://www.rollingstone.com/music/music-features/lilnas-x-old-town-road-streaming-record-819468/

Lewis, G. H. (1997). Lap dancer or hillbilly deluxe? The cultural constructions of modern country music. Journal of Popular Culture, 31(3), 163-173. https://doi.org/10.1111/j.0022$\underline{3840.1997 .3103 \_163 . x}$

Lewis, G. H. (2001). The color of country: Black influence and experience in American country music. Popular Music and Society, 25(3-4), 107-119.

https://doi.org/10.1080/03007760108591803

Light, A. (2020). hip-hop | Definition, History, Culture, \& Facts. Encyclopedia Britannica. https://www.britannica.com/art/hip-hop 
Maddux, J. E., \& Rogers, R. W. (1983). Protection motivation and self-efficacy: A revised theory of fear appeals and attitude change. Journal of Experimental Social Psychology, 19(5), 469-479. https://doi.org/10.1016/0022-1031(83)90023-9

Moss, M. R. (2019, May 1). Lil Nas X's ‘Old Town Road 'sounds like country's future. So why has Nashville snubbed it? Los Angeles Times. https://www.latimes.com/entertainment/music/la-et-ms-lil-nas-X-old-town-road-nashvillecountry-20190501-story.html

Neal, M. A. (2005). White chocolate soul: Teena Marie and Lewis Taylor. Popular Music, 24(3), 369-380. https://doi.org/10.1017/S0261143005000577

Nittle, N. (2019, June 5). Lil Nas X isn't an anomaly - black people have always been a part of country music. Https:/Www.Vox.Com/the-Goods/2019/6/5/18653880/Lil-Nas-XCountry-Music-Billboard-Wrangler-Old-Town-Road. https://www.vox.com/thegoods/2019/6/5/18653880/lil-nas-X-country-music-billboard-wrangler-old-town-road

Omi, M., \& Winant, H. (1994). Racial Formation in the United States: From the 1960s to the 1990s (Critical Social Thought) (2nd ed.). Routledge.

Reilly, D. (2019, April 4). Lil Nas X’s ‘Old Town Road 'Was Destined to Disrupt. Vulture. https://www.vulture.com/2019/04/lil-nas-X-old-town-road-controversy-explained.html 
Rogers, R. W. (1975). A Protection Motivation Theory of Fear Appeals and Attitude Change1. The Journal of Psychology, 91(1), 93-114.

https://doi.org/10.1080/00223980.1975.9915803

Rose, T. (1994). Black Noise: Rap Music and Black Culture in Contemporary America (Music / Culture) (Illustrated ed.). Wesleyan University Press.

Russell, T. (2010). Country Music Originals : The Legends and the Lost: The Legends and the Lost (Illustrated ed.). Oxford University Press, USA.

Shoemaker, P. J., \& Vos, T. (2009). Gatekeeping Theory. Taylor \& Francis.

The Editors of Encyclopaedia Britannica. (2020a). rap | History, Artists, \& Facts. Encyclopedia Britannica. https://www.britannica.com/art/rap

The Editors of Encyclopaedia Britannica. (2020b, December 1). country music | Definition, Artists, History, \& Facts. Encyclopedia Britannica. https://www.britannica.com/art/country-music 